\title{
PENDAMPINGAN INDUSTRI LOKAL ANYAMAN BAMBU UNTUK MENINGKATKAN DAYA SAING PASAR DI DESA BINAAN DUSUN KEDAMPUL KECAMATAN TUMPANG KABUPATEN MALANG
}

\author{
Singgih Susilo*, Budijanto, Marhadi Slamet Kistiyanto, Rudi Hartono, Nailul Insani \\ singgih.susilo.fis@um.ac.id
}

Jurusan Geografi, Fakultas IImu Sosial, Universitas Negeri Malang

Diterima 11 April 2019, dipublikasikan 30 April 2019

\begin{abstract}
Abstrak
Dusun Kedampul Desa Duwet memiliki potensi alam bambu yang melimpah. Sampai saat ini pemanfaatan bambu belum maksimal baik dari segi kuantitas dan kualitas padahal bambu dapat dijadikan berbagai kerajinan anyaman maupun non anyaman. Berdasarkan hal tersebut maka dipilihlah Dusun Kedampul Desa Duwet sebagai lokasi untuk melaksanakan Pengabdian Kepada Masyarakat (PKM). Kegiatan PKM yang dilaksanakan berupa pelatihan, dengan tahapan sebagai berikut: (1) tahap persiapan, (2) tahap pelaksanaan proses dan (3) tahap pemandirian. Pelaksanaan kegiatan Pengabdian kepada Masyarakat ini dilaksanakan pada bulan Januari - November 2018 yaitu berupa kegiatan: pendidikan dan pelatihan kerajinan anyaman berbahan baku bambu. Beberapa manfaat praktis yang diharapkan dari pelaksanaan PKM, yaitu: (1) mereka mendapatkan informasi yang jelas dan utuh mengenai hakekat pemberdayaan masyarakat dari segi pengetahuan dan keterampilan, bermakna untuk penciptaan lapangan pekerjaan baru yang sifatnya inovatif dari kerajinan anyaman bambu; (2) masyarakat yang menjadi peserta pelatihan memperoleh gambaran yang jelas mengenai langkah pengembangan iklim usaha dengan memanfaatkan komoditas lokal; (3) peserta pelatihan juga mendapatkan gambaran yang jelas dan utuh tentang manfaat hasil komoditi lokal apabila dikelola dengan baik akan mendatangkan nilai finansial.
\end{abstract}

Kata Kunci: Pelatihan Keterampilan, Anyaman Bambu

\section{PENDAHULUAN}

Bambu merupakan sumberdaya alam yang dapat diperbaharui dan memegang peranan penting dalam kehidupan masyarakat pedesaan. Bambu dikenal oleh masyarakat memiliki sifat-sifat yang baik untuk dimanfaatkan, diantaranya batangnya kuat, ulet, lurus, rata, keras, mudah dibelah, mudah dibentuk dan mudah dikerjakan serta ringan sehingga mudah diangkut. Bambu juga memiliki keunggulan dari segi ekonomi, ekologi, dan sosial-budaya. Keunggulan tersebut diantaranya bambu cepat tumbuh hingga menjadi sumber penghasilan, dapat mengurangi polusi udara dan air, pengendali erosi dan tanah longsor. Oleh karena itu, tanaman bambu sangat sesuai untuk merehabilitasi lahan kritis, konservasi tanah miring dan rawan longsor serta dipergunakan untuk estetika lingkungan dan mata pencaharian pokok masyarakat.

Bambu sebagai mata pencaharian pokok dewasa ini lebih pada hasil kerajinan bambu dalam bentuk anyaman. Anyaman adalah teknik membuat karya seni rupa yang dilakukan dengan cara menumpang tindihkan (menyilangkan) bahan anyam berupa lungsi dan pakan. Lungsi merupakan bahan anyaman yang menjadi dasar dari media anyam, sedangkan pakan yaitu bahan anyaman yang digunakan sebagai media anyaman dengan cara memasukkannya ke dalam bagian lungsi yang sudah siap untuk dianyam. Menurut Hoenigman, anyaman merupakan wujud kebudayaan, yang termasuk dalam artefak. Artefak adalah wujud kebudayaan fisik yang berupa hasil dari aktivitas, perbuatan, dan karya semua manusia dalam masyarakat berupa benda-benda atau hal-hal yang dapat diraba, dilihat, dan didokumentasikan. Anyaman pertama kali digunakan manusia, yaitu untuk membantu dalam kehidupannya sehari-hari (BPS, 1983).

Kerajinan berbahan dasar bambu memiliki sejarah yang cukup panjang dalam produk yang dihasilkan oleh masyarakat lokal di Indonesia. Selain dikarenakan bahan yang cukup ekonomis, hasil kerajinan yang diupayakan juga dapat bermacam-macam, tidak hanya sebagai produk furniture, tetapi 
Pendampingan Industri Lokal Anyaman Bambu Untuk

juga kerajinan lain sebagai penunjang aktivitas kuliner. Keberadaan bahan dasar yang cukup melimpah menjadikan salah satu faktor pendorong berkembangnya hasil kerajinan dari usaha mikro kecil menengah (UMKM) atau industri kecil menengah (IKM) berbahan dasar bambu. Hal ini selaras dengan letak Indonesia di wilayah tropis yang mendukung persebaran tanaman bambu, tidak terkecuali di desa binaan Jurusan Geografi, FIS UM.

Desa binaan Jurusan Geografi terletak di Dusun Kedampul, Desa Duwet, Kecamatan Tumpang, Kabupaten Malang. Secara Geografis, wilayahnya berada di lereng kaki Gunung Bromo, Semeru dan Tengger bagian barat yang berada pada elevasi 700 hingga 1500 meter di atas permukaan air laut. Dusun Kedampul merupakan satu dari dua dusun yang berada di Desa Duwet yang mencakup 4 RW dan 28 RT. Luas wilayahnya mencakup $1.213 \mathrm{Ha}$, dimana pada bagian utara berbatasan dengan Desa Benjor, sebelah timur dan selatan berbatasan dengan Desa Duwet Krajan, serta sebelah barat dengan Desa Tulus Ayu.

Secara demografi, Desa Duwet (lokasi Dusun Kedampul) memiliki penduduk sebanyak 3.715 jiwa (BPS, 2015), dimana terdiri atas 1.880 penduduk berjenis kelamin laki-laki serta 1.835 penduduk dengan jenis kelamin perempuan. Dari jumlah tersebut, terkelompokkan menjadi $1.205 \mathrm{KK}$. Aspek kesejahteraan sosial tentang perekonomian desa dapat dikatakan cukup berkembang, karena sektor yang diupayakan tidak hanya terkonsentrasi pada bidang pertanian saja, akan tetapi telah berkembang ke sektor lain meliputi perdagangan skala kecil dan menengah, jasa transportasi, serta kerajinan UMKM berupa anyaman bambu, utamanya besek dan tusuk sate. Secara keseluruhan potensi Desa Duwet cukup baik, meliputi potensi sumberdaya alamnya (SDA) ataupun potensi sumberdaya manusiannya (SDM), yang dapat dimanfaatkembangkan untuk peningkatan masyarakat secara umum.

Produk anyaman bambu berupa wadah makanan (besek) serta tusuk sate yang dihasilkan oleh masyarakat lokal di desa binaan Kedampul sudah berjalan cukup lama dilakukan oleh warga lokal. Penggandengan kerjasama instansi pemerintah, dalam hal ini Dinas Perindustrian sangat tepat untuk mengambangkan potensi yang masih belum tergarap secara baik di desa binaan Jurusan Geografi FIS UM ini. Selain itu, hal ini juga turut mendorong pengembangan produk unggulan yang selaras dengan program pemerintah, baik pada level nasional maupun level daerah atau kabupaten.

Kegiatan ini selaras dengan Peraturan Menteri Perindustrian Nomor 78/M.IND/PER/9/2007 (Suyono, 1996) tentang peningkatan efektifitas pengembangan Industri Kecil dan Memengah (IKM) melalui Pendekatan Satu Desa Satu Produk (One Village One Product - OVOP); Peraturan Menteri Dalam Negeri Republik Indonesia Nomor 9 Tahun 2014 Tentang Pedoman Pengembangan Produk Unggulan Daerah; serta SK Bupati Malang Nomor 180/1185/KEP/421.013/2013 (BKKBN, 2014) tentang Produk Unggulan Kecamatan Melalui Pendekatan Satu Desa Satu Produk (One Village One Product-OVOP).

Observasi untuk melihat potret, profil dan kondisi khalayak sasaran telah dilakukan di desa binaan Kedampul, Tumpang. Berdasarkan hasil observasi tersebut dapat diketahui; pertama bahwa bahan baku bambu sangat berlimpah terutama jenis bambu tali/apus (Gigantochloa apus). Jenis bambu ini amat liat dengan jarak ruas sampai $65 \mathrm{~cm}$, diameter $40-80 \mathrm{~mm}$ dan panjang $6-13 \mathrm{~m}$. Bambu ini tumbuh di daerah tropis yang lembab dan juga di daerah yang kering (Basundara, 2017). Kedua, Produk hasil kerajinan anyaman dan hasil kerajinan bambu lain masih terbatas pada tempat makanan (besek dan tusuk sate) dengan kapasitas produksi rumah tangga yang memadai. Ketiga, terdapat potensi dari masyarakat lokal untuk dilakukan pendampingan kerajinan anyaman bambu lain, untuk meningkatkan kapasitas dan keterampilan warga.

Berdasarkan hasil observasi yang dilakukan, permasalahan yang dijumpai di lapangan yaitu produk kerajinan anyaman bambu (besek) yang belum maksimal secara kualitas. Artinya, produk tersebut secara teknik dan model masih terdapat banyak kekurangan yang berakibat tidak terpenuhinya kebutuhan pasar. Keterbatasan ini mengakibatkan produk anyaman bambu (besek) hanya bisa dipasarkan secara terbatas. Selain itu, variasi produk yang terbatas mengakibatkan nilai jual yang dihasilkan kurang maksimal. Berdasarkan hal tersebut sangat perlu dikembangkan varian hasil anyaman bambu lain agar daya jual semakin tinggi. Pengembangan produk yang bervariasi dan bernilai jual tinggi dapat dilakukan melalui pendampingan keterampilan oleh narasumber yang kompeten, baik 
dalam pengembangan model, teknik, dan varian produk, juga pendampingan keterampilan dalam strategi pemasaran yang dibutuhkan oleh pasar.

\section{Permasalahan Mitra}

Secara rinci permasalahan mitra di lokasi pengabdian kepada masyarakat dapat dijelaskan sebagai berikut: (1) terbatasnya alat pembuat kerajinan bambu yang dimiliki oleh kelompok pengrajin anyaman bambu tradisional. Para kelompok pengrajin rata-rata hanya mempunyai pisau dan golok sehingga memperlambat proses produksi; (2) jenis produk yang dihasilkan sangat terbatas yaitu hanya pagar bambu, anyaman bambu untuk dinding, peralatan dapur dan makanan (besek dan tusuk sate). Mereka memproduksi tersebut karena sederhana dan tidak rumit. Sedangkan apabila ingin memproduksi produk yang lebih bervariasi maka dibutuhkan keterampilan khusus dan peralatan penunjang; (3) kurangnya pengetahuan bagi kelompok pengrajin bambu dalam bidang pemasaran, mereka memasarkan produk dengan cara keliling atau dijual ke pengepul sehingga penjualan produk sangat kecil; (4) masih terbatasnya wilayah pemasaran, hal ini disebabkan karena kelompok pengrajin bambu tidak mempunyai hubungan jaringan distribusi pemasaran produk yang luas, sehingga untuk melempar barang mengalami kesulitan. Hal ini dibutuhkan pelatihan dan pengetahuan strategi pemasaran yang tepat.

Berdasarkan pemaparan permasalahan tersebut, maka pengabdian kepada masyarakat ini secara praktis diharapkan mempunyai manfaat terutama bagi masyarakat desa binaan Jurusan Geografi, terkait dengan kegiatan ini: (1) manfaat bagi masyarakat yakni memberikan keterampilan lebih atau tambahan bagi warga binaan Kedampul yang dipilih dalam dua Dasa Wisma mengenai produk kerajinan ayaman bambu lain (diversifikasi produk), serta membekali masyarakat lokal Kedampul untuk dapat membuat struktur organisasi yang diharapkan mempermudah manajemen pemasaran kerajinan tangan secara mandiri; (2) meningkatkan hasil usaha mikro kecil menengah (UMKM) dalam tingkat kabupaten untuk dikembangkan lebih jauh lagi dalam sisi variasi produk serta produktivitasnya; (3) turut serta mewujudkan tri dharma perguruan tinggi mengenai pengabdian masyarakat dengan memberikan jaringan kerja sama antara pihak dusun dengan Dinas Perindustrian Kabupaten Malang sebagai desa binaan yang merupakan wujud kepedulian terhadap kerajinan masyarakat.

\section{Pendampingan Keterampilan Bagi Pengrajin Anyaman Bambu Oleh Narasumber Yang Kompeten Terkait Teknik Pembuatan Anyaman Bambu Yang Lebih Bervariasi Dari Segi Model Dan Desain Yang Mempunyai Nilai Jual Tinggi}

Kreativitas sangat diperlukan dalam mengembangkan produk anyaman bambu menjadi lebih bervariasi model dan desainnya. Kreativitas merupakan kemampuan untuk melihat dan memikirkan hal-hal yang luar biasa, mencetuskan solusi-solusi baru atau ide-ide yang menunjukkan kelancaran, kelenturan dan orisinil dalam berpikir (Dekranas, 2011). Sedangkan design produk adalah kunci kesuksesan sebuah produk menembus pasar sebagai basic bargain marketing, mendesain sebuah produk berarti membaca sebuah pasar, kemauan mereka, kemampuan mereka, pola pikir mereka serta banyak aspek lain yang akhirnya diterjemahkan dan diaplikasikan dalam perancangan sebuah produk. Kemampuan sebuah produk bertahan dalam siklus sebuah pasar ditentukan oleh bagaimana sebuah desain mampu beradaptasi akan perubahan-perubahan dalam bentuk apapun yang terjadi dalam pasar yang dimasuki produk tersebut, sehingga kemampuan tersebut menjadi nilai keberhasilan bagi produk itu sendiri dikemudian hari.

Masyarakat pengrajin bambu yang ada di Dusun Kedampul saat ini masih eksis menjalankan usaha kerajinan anyaman bambu, terutama besek dan tusuk sate. Kelompok pengrajin anyaman bambu di Dusun Kedampul tidak pernah menerima pengetahuan dan keterampilan khusus dalam pembuatan produk kerajinan dari bambu seperti variasi model anyaman bambu terutama besek. Variasi model misalnya dari segi warna yang bisa diwarnai menggunakan cat, kemudian variasi pada bentuk, dan tentunya kualitas irat-an bambu yang halus dan tidak tajam. Mereka selama ini hanya mampu membuat pagar bambu dan anyaman bambu biasa saja, walaupun sebenarnya mereka ingin mengembangkan produk anyaman bambu dengan berbagai variasi. 
Berdasarkan hal tersebut kegiatan pengabdian kepada masyarakat dilakukan transfusi IPTEK dalam hal keterampilan proses produksi anyaman bambu di Dusun Kedampul. Transfusi IPTEK ke dalam kelompok pengrajin anyaman bambu sekaligus melakukan pemberdayaan terhadap semua anggota pada kelompok usaha tersebut, sehingga dapat melakukan pengelolaan usaha kerajinan bambu secara profesional. Produk teknologi sebagai bentuk solusi yang ditawarkan untuk mengatasi permasalahan kelompok pengrajin bambu di Dusun Kedampul Desa Duwet adalah: (1) pemberian materi oleh narasumber terkait dengan bahan jenis bambu yang cocok untuk anyaman, model-model anyaman bambu yang diminati oleh pasar milenial; (2) teknik pemotongan, peng-irat-an, dan penghalusan bambu menjadi serat bambu agar keajegan dan keindahan serat bambu terjaga; (3) penganyaman bentuk dasar yang disertai pewarnaan sehingga warna yang dihasilkan bisa bervariasi atau penambahan aksesori lukisan unik khas Dusun Kedampul Desa Duwet; (4) teknik pembentukan anyaman bambu yang menghasilkan produk kerajinan sehingga akan dihasilkan bermacam-macam bentuk kerajinan; (5) proses praktek menganyam bagi peserta yang didampingi oleh narasumber. Secara keseluruhan produksi anyaman bambu dapat dilihat pada bagan gambar 1 .

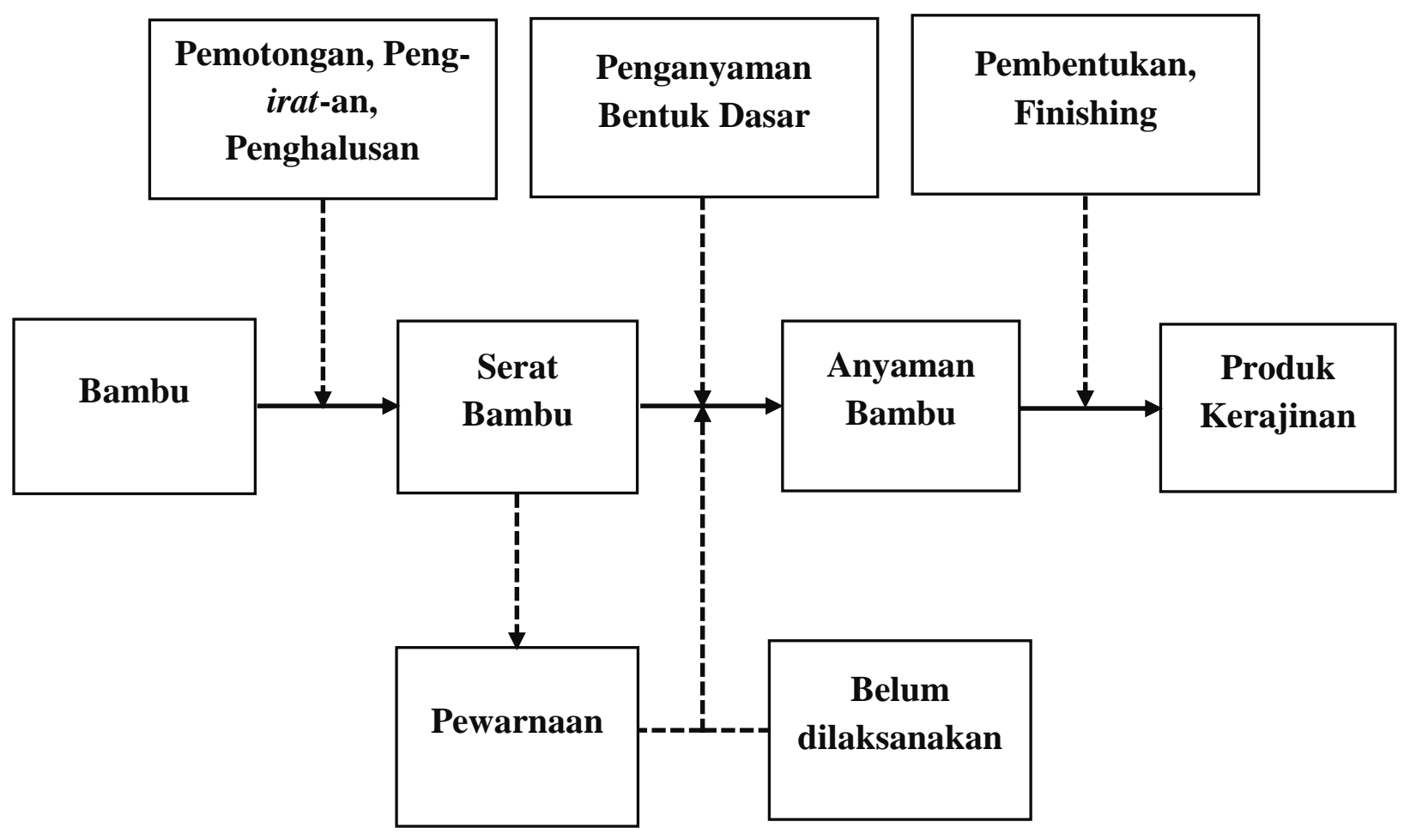

Gambar 1. Proses Produksi Kerajinan Anyaman Bambu

Kegiatan pemotongan hingga penghalusan tiap ruas bambu merupakan tahapan yang sangat penting pada produksi produk kerajinan anyaman bambu. Tahapan inilah yang membedakan antara produk kerajinan yang satu dengan produk kerajinan lain yang menggunakan iratan kasar pada serat bambu seperti pada pembuatan tampah dan dinding/bilik bambu (gedek dalam bahasa Jawa). Setelah melewati tahapan ini akan diperoleh hasil berupa serat-serat bambu yang tipis dan halus. Serat bambu selanjutnya dapat langsung dianyam sesuai bentuk dasar seperti sasak, serong dan truntum. Untuk mendapatkan hasil yang menarik serat bambu juga dapat diberi warna dengan cara direbus pada air yang telah diberi pewarna dan dikeringanginkan setidaknya dalam waktu 12 jam. Dari bentuk dasar yang telah dibuat, selanjutnya dapat dibentuk sesuai dengan kreasi dan inovasi pengrajin. Proses akhir (finishing) dilakukan dengan penyemprotan produk kerajinan dengan menggunakan vernis untuk memperkilap, mengawetkan dan memperkuat karakter bambu yang dihasilkan.

Solusi yang diuraikan tersebut dimaksudkan agar kelompok pengrajin anyaman bambu dengan didampingi oleh narasumber yang berkompeten dapat melakukan pengembangan produk. 
Keberhasilan pengembangan produk ditentukan oleh empat faktor (four key success factors), yaitu tingginya kualitas proses produk baru, pemahaman strategi produk baru di setiap level usaha, komitmen sumberdaya, yaitu sumberdaya manusia dan dana, serta inovasi dalam menggagas pengembangan produk baru. Keberhasilan pengembangan produk akan berdampak pada dihasilkannya produk yang lebih unggul (Farelly, 1996).

Luaran pada solusi tersebut adalah peningkatan keterampilan pengrajin anyaman bambu dalam menghasilkan kerajinan anyaman bambu yang berkualitas dan memiliki nilai seni serta jual yang baik. Luaran selanjutnya yaitu video kegiatan proses pendampingan dari awal kegiatan hingga akhir yang menampilkan pemberian materi oleh narasumber dan praktik produksi kerajinan anyaman bambu. Buku tentang kerajinan anyaman bambu khas Dusun Kedampul Desa Duwet Malang juga menjadi luaran yang diharapkan akan dapat diterbitkan sebagai panduan bagi pengrajin anyaman bambu.

\section{Pendampingan Dalam Pemasaran Produk Oleh Narasumber Yang Kompeten Terkait Strategi Yang Diperlukan Untuk Memasarkan Hasil Kerajinan Anyaman Bambu Secara Luas}

Keberhasilan suatu usaha baik usaha kecil maupun besar dapat dilihat dari bagaimana usaha tersebut mampu memasarkan produk yang dihasilkan. Hal ini tentunya juga termasuk bagaimana menarik konsumen untuk berminat terhadap produk dan melakukan transaksi pembelian produk tersebut. Untuk menarik minat beli konsumen terhadap produk yang dihasilkan, maka suatu industri rumahan atau pengrajin harus mampu memutuskan apa dan bagaimana strategi yang akan dijalankan. Strategi pemasaran merupakan serangkaian rencana yang dilakukan untuk mencapai tujuan yang diharapkan dan ditetapkan. Penentuan strategi secara tepat akan memberikan pengaruh terhadap keberhasilan suatu usaha dalam melakukan kegiatan pemasaran.

Menurut Assauri (dalam Irhas, 2010), strategi pemasaran adalah rencana yang menyeluruh, terpadu dan menyatu di bidang pemasaran, yang memberikan panduan tentang kegiatan yang akan dijalankan untuk dapat tercapainya tujuan pemasaran suatu usaha. Masing-masing usaha tentunya memiliki strategi khusus dan berupaya untuk menjadi paling unggul dibandingkan dengan usaha lain. Berdasarkan hal tersebut, maka dalam usaha kerajinan anyaman bambu perlu strategi tertentu agar hasil kerajinan anyaman bambu di Dusun Kedampul-Duwet ini laku dipasaran dan memiliki nilai jual yang baik.

Strategi pemasaran yang direncanakan untuk kelompok pengrajin anyaman bambu di Dusun Kedampul-Duwet ditempuh melalui: (1) inovasi Produk, terkait dengan pendampingan keterampilan oleh narasumber berkaitan dengan pengembangan model dan desain kerajinan anyaman bambu. Manfaat dilakukannya inovasi produk adalah untuk memberikan kepuasan kepada konsumen dan juga meningkatkan volume penjualan yang nantinya secara tidak langsung akan mempengaruhi peningkatan laba yang didapatkan; (2) harga, penetapan harga disesuaikan dengan situasi dan kondisi lingkungan sasaran pasar, tujuannya agar produk bisa diterima pembeli dengan baik dan tidak merasa keberatan atas harga yang telah ditetapkan; (3) promosi, tujuan dilakukannya adalah mencari, mempengaruhi dan menjaring pembeli sebanyak mungkin karena dengan adanya promosi akan memudahkan produsen untuk mencari pembeli dan meyakinkan pembeli agar tetap setia kepada produk yang dihasilkan oleh produsen; (4) tempat, pemilihan tempat untuk memasarkan produk agar sampai kepada pasar sasaran secara tepat produsen menempuh dengan jalan saluran distribusi langsung atau tidak langsung. Distribusi langsung yang ditempuh produsen dapat dengan cara memasarkan produk langsung ke tangan konsumen. Sedangkan, distribusi tidak langsung dilakukan dengan cara menggunakan jasa atau perantara dalam pemasaran; (5) pemasaran berbasis e-comerse. Pemasaran ini telah membuka paradigma baru dalam pemasaran dan pengenalan produk secara cepat dan efisien dibandingkan cara konvensional dengan menjual melalui toko atau gerai. Saat ini tidak ada satupun usaha yang tidak bersentuhan dengan e-comerse dan diprediksikan e-comerse saat ini telah menjadi salah satu bagian penting dalam usaha yang menempati posisi sejajar dengan bagian keuangan, produksi atau pemasaran (McClure, 1972). Pemasaran e-comerse bisa dilakukan dengan cara yang sederhana terlebih dahulu yakni menggunakan sosial media yang dimiliki oleh kelompok pengrajin anyaman bambu. 


\section{METODE PELAKSANAAN \\ Metode Pelaksanaan Program Pengabdian}

Berdasarkan identifikasi masalah yang telah diuraikan maka, kami menawarkan solusi permasalahan melalui serangkaian kegiatan dengan melibatkan partisipasi aktif dari kelompok pengrajin anyaman bambu "IRAT APUS" di desa binaan Jurusan Geografi di Dusun Kedampul-Duwet sebagai berikut: (1) memberikan sosialisasi ke warga Dasa Wisma yang berisi tentang keterampilan inovasi kerajinan bambu, tidak hanya sebagai wujud kerajinan anyaman besek, tetapi keterampilan kerajinan anyaman bambu lainnya yang mempunyai nilai jual tinggi, media sosialisasi yang digunakan berupa poster dan buku materi sebagai pengetahuan kepada warga Dasa Wisma di desa binaan; (2) pembentukan struktur organisasi yang bertujuan untuk memudahkan pembagian tugas dan pekerjaan supaya pelatihan keterampilan anyaman bambu tersebut berjalan dengan lancar; (3) pendampingan dengan bekerja sama dengan narasumber dan Dinas Perindustrian Kabupaten Malang untuk warga Dasa Wisma dalam hal perizinan sampai dengan pemasaran hasil keterampilan bambu tersebut. Metode yang digunakan dalam kegiatan ini adalah pendampingan keterampilan oleh narasumber melalui pelatihan. Tahapan pelatihan ini terbagi menjadi dua kegiatan yakni persiapan dan pelaksanaan.

\section{Persiapan}

Pada tahapan ini panitia melakukan koordinasi dengan pihak desa dan kelompok pengarajin anyaman bambu. Melakukan rekrutmen peserta, rekrutmen peserta dilakukan dengan menjalin komunikasi yang baik dengan kelompok pengrajin anyaman bambu. Rekrutmen peserta dilakukan dengan memperhatikan jenis kelamin, artinya proporsi yang dititikberatkan adalah kepada ibu rumah tangga yang memiliki banyak waktu luang. Namun, baik pria maupun wanita, asal memenuhi kriteria, dipandang mau dan mampu mengikuti pelatihan dan dipandang bersedia untuk menerapkan ilmu yang diperoleh pada pelatihan.

\section{Pelaksanaan}

Pelaksanaan pelatihan keterampilan pembuatan kerajinan anyaman bambu dengan model pelatihan keterampilan berkelanjutan. Pelatihan keterampilan dilakukan sebagai motivasi masyarakat untuk belajar membaca peluang usaha. Pembelajaran akan dilakukan seminggu 2 kali. Waktu yang agak senggang itu kami terapkan dengan maksud memberikan kesempatan kepada peserta pelatihan untuk menerapkan ilmu yang diperoleh di rumah masing-masing. Karena peserta pelatihan sebagain besar telah diberikan keterampilan yang berguna untuk dirinya masing-masing.

Evaluasi tidak dilakukan dengan menyediakan waktu khusus. Tapi penilaian dilakukan secara berkesinambungan oleh para narasumber selama proses pelatihan dilakukan. Penilaian dilakukan dengan memberikan tes keterampilan kepada warga belajar. Penilaian diberikan dalam bentuk angka oleh masing-masing narasumber, yang berisikan prestasi dalam bidang teori dan praktek untuk masingmasing kompetensi. Nilai akhir adalah nilai rata-rata dari semua narasumber.

\section{HASIL DAN PEMBAHASAN}

Difusi teknologi dalam furnishing bahan baku bambu dilakukan dengan memodifikasi teknik pemotongan, peng-irat-an, penghalusan yang sudah dilakukan pada kelompok pengrajin anyaman bambu. Sedangkan teknik pewarnaan belum pernah dilakukan sama sekali oleh kelompok pengrajin ini. Dengan demikian produk kerajinan anyaman bambu yang dihasilkan tersebut dapat dilakukan proses artistik dengan efek dekoratif pewarnaan melalui proses pelelehan zat pewarna dan melukis serat bambu baik yang belum dianyam atau sudah dianyam secara manual dengan zat pewarna. Cara pendekorasian tersebut merupakan cara sederhana untuk mendapatkan efek warna dari kerajinan anyaman bambu.

Kegiatan ini dilaksanakan dalam bentuk pelatihan ketrampilan melalui pendampingan nara sumber sebagai ahli dalam ketrampilan industri anyaman bambu, kepada khalayak sasaran yang terdiri 
sasaran utama yaitu para keluarga yang memeilki pekerjaan sampingannya sebagai penganyam bambu. Kegiatan berikutnya setelah pelatihan dengan model demontrasi contoh, adalah praktik pembuatan salah satu jenis anyaman bambu Besek. Jenis anyaman tersebut dipilih karena kebutuhan pasar yang masih cukup tinggi.

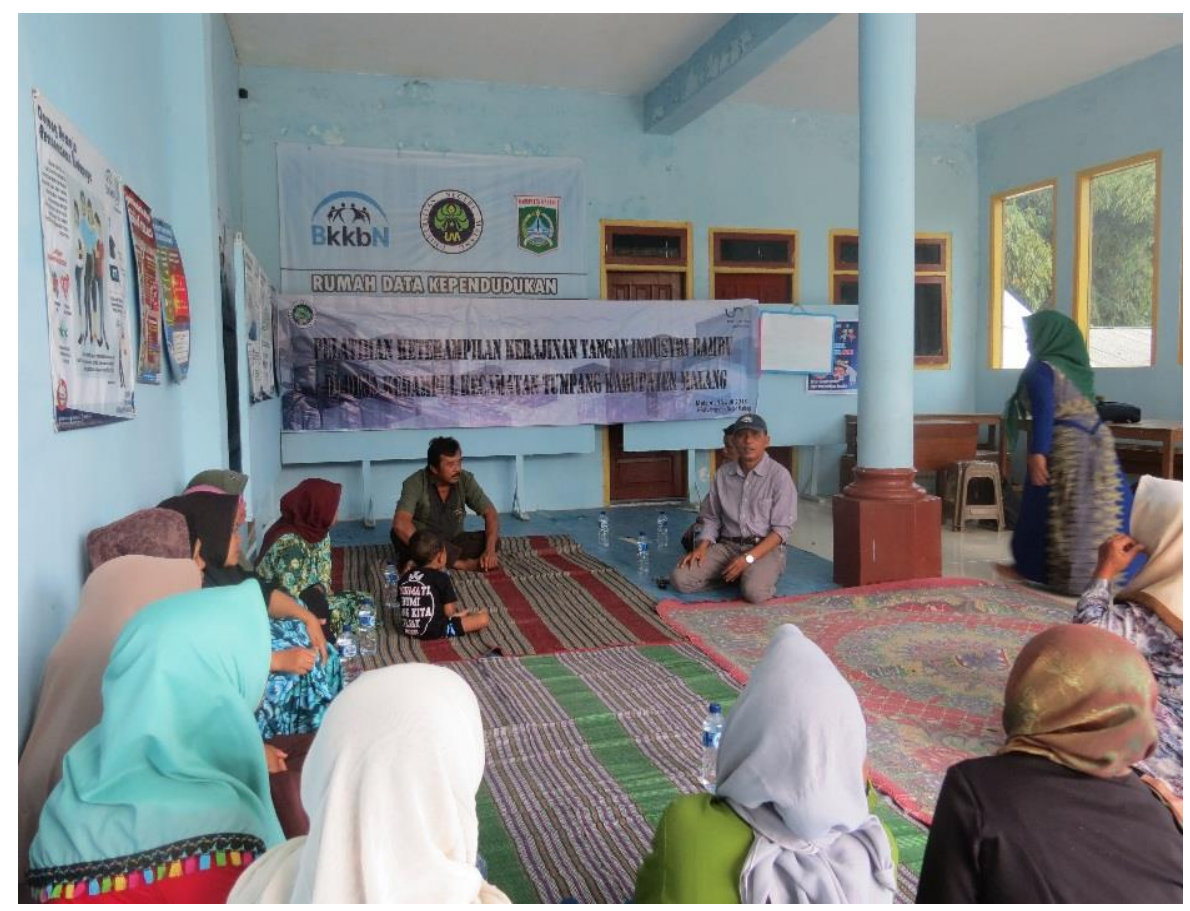

Gambar 1. Diskusi dan Wawancara dengan kelompok pengarajin bambu di Dusun Kedampul, Tumpang-Malang

Pada awal kegiatan keterampilan pembuatan besek, para peserta ibu rumah tangga) diajak berdiskusi dan tanya jawab tentang pembuatan beberapa keterampilan anyaman bambu dan peluang pemasarannya. Diskusi menyangkut sudah berapa lama ibu ibu melakukan pekerjaan sampingan ini, juga diskusi bahan jenis bambu yang cocok untuk anyaman besek maupun jenis lain, Pada acara diskusi awal ini banyak tanggapan yang diajukan oleh ibu ibu rumah tangga, khususnya mengelucut keluhan keluahan tentang pemasaran yang selema ini dialami. Dijelaskan dalam diskusi oleh narasumber (Bapak Saperlan) bahwa jenis bambu yang cocok untuk Industri kerajinan tangan anyaman bambu adalah jenis bambu Apus, ciri-cirinya seratnya halus dan tidak mudah patah.

Selanjutnya diberikan presentasi dan diskusi materi praktek pembuata anyaman besek, yang sebelumnya oleh narasumber dijelaskan bahwa dari semua jenis industry anyaman bambu, jenis besek merupakan produk yang banyak diminta dipasaran, jenis jenis lainnya seperti Tompo, Kukusan dan Tenggok diproduksi hanya kalau ada permintaan pasar. Ibu-ibu peserta pedampingan ternyata sudah tidak asing dengan produk besek, bahkan menurut kami kerika mempraktekan membuat besek sangat cepat, tidak ada satu jam bisa menyelesaikan satu tangkep besek ukuran kecil. Catatan oleh narasumber ibu-ibu sebenarnya sudah terampil dalam mempraktikan, hanya pekerjaan produknya kurang rapi dan kurang halus, menerurutnya apabila hasil produk ibu-ibu tersebut belum bisa dipasarkan pada penjual penjual langganannya.

\section{Faktor Pendukung}

Keterlakasanaan program ini dapat berjalan dengan baik karena terdapat beberapa faktor pendukung, yaitu: (1) kegiatan para keluarga miskin sebagai sasaran utama program pelatihan pola perilaku hidup bersih dan sehat melalui pembuatan SPAL dan kesediaan para guru TK, SD, MI maupun para pengurus kader kesehatan desa sebagai sasaran antara yang memotivasi sasaran utama program ini; (2) antusiasme para peserta pelatihan dalam mengikuti kegiatan ditunjukkan dengan kesungguhan dan semangat dalam diskusi dan tanya jawab dengan narasumber saat pelatihan; (3) 
kesadaran dan animo masyarakat miskin yang cukup baik mengenai kesadaran berperilaku hidup bersih dan sehat.

\section{Faktor Penghambat}

Secara umum faktor penghambat yang muncul dapat diatasi dengan melakukan diskusi dan komunikasi dengan TIM SATGAS pengabadian masyarakat dengan melibatkan sasaran antara yakni para guru TK, SD, MI dan para pengurus kader kesehatan. Faktor penghambat tersebut adalah: (1) tempat tinggal para keluarga miskin kebanyakan berada dilingkungan kumuh, sehingga fungsi rumah belum menunjang perilaku hidup bersih dan sehat; (2) status para guru dan para pengurus kader kesehatan sebagai sasaran antara yang berfungsi sebagai motivator sasaran untuk program, bertempat tinggal diluar desa sasaran.

Pendampingan kerajinan anyaman bambu "besek" ini diawali dengan diskusi dan wawancara dengan pengrajin untuk menemukan permasalahan dan selanjutnya memberikan berbagai solusi.

\section{Pemberian Materi: Inovasi Dalam Pembuatan Kerajinan Anyaman Bambu "Besek"}

Hal yang pertama dilakukan adalah melakukan persiapan kegiatan pelaksanaan pemberian materi kepada para pengrajin anyaman bambu "besek" di Dusun Kedampul, Desa Duwet, Kecamatan Tumpang Kabupaten Malang. Pada tahap awal, pemberian materi meliputi teknik pembuatan "besek" yang terdiri dari: (1) pemilihan bahan baku bambu; (2) pemotongan, peng-irat-an, dan penghalusan bambu menjadi serat bambu; (3) penganyaman; (4) pewarnaan; dan (5) finishing produk.

\section{Pemilihan Bahan Baku Bambu}

Bambu yang biasa dijadikan sebagai bahan anyaman bukanlah sembarang bambu. Bambu yang digunakan adalah: bambu yang memiliki serat lebih halus dari jenis bambu biasa. Bambu jenis ini disebut dengan bambu tali. Istilah tersebut nampaknya muncul karena ketika bambu jenis ini di iris dan dijadikan sebagai tali ternyata wulet. Kewuletan itu antara lain karena memiliki serat yang halus. Sebagai bahan anyaman sebaiknya kita pilih bambu tali yang masih agak muda. Supaya produk yang dihasilkan bermutu tinggi, maka bambu yang hendak digunakan sebagai bahan baku harus memenuhi beberapa persyaratan, yaitu; ruasnya panjang, agar diperoleh anyaman yang lebar dan sesuai dengan ukuran yang dikehendaki dan seratnya cukup padat dan kuat.

\section{Pemotongan, Peng-irat-an, dan Penghalusan}

Tahap awal adalah melakukan penebangan bambu membersihkan ranting-rantingnya. Pemotongan bambu dapat dilakukan dengan menggunakan parang atau gergaji. Pemotongan dilakukan dengan hati-hati, pemotongan batang bambu untuk bahan anyaman dianjurkan untuk memakai gergaji potong yang bergigi halus. Untuk bambu jika kulit batang digunakan, hendaknya diusahakan jangan sampai kulit tersebut terkelupas, terutama waktu pemotongan ruasnya. Untuk bahan anyaman, panjang ruas bambu yang ideal adalah 50 atau $60 \mathrm{~cm}$.

Tahap selanjutnya adalah melakukan pembelahan bambu yang sudah dibersihkan dan dipotong. Cara yang dapat dilakukan yaitu; mula-mula bambu dibagi dua sama besar, lalu masing-masing bagian dibagi dua lagi sehingga setiap bagian berukuran seperempat. Tahap selanjutnya bagi pula setiap bagian itu menjadi dua. Setelah mencapai seperenambelas bagian, maka bahan itu dijemur atau diletakkan di tempat terbuka tetapi tidak sampai kena hujan. Setelah didiamkan barang lima atau tujuh hari, maka pengolahan bahan ini dapat kita lanjutkan.

Setelah bambu-bambu dibelah sesuai dengan ukuran yang dikehendaki, untuk anyaman halus lebar belahan akhir 3-4 mm sedang untuk anyaman pakai (alat-alat dapur) lebar belahan akhir yaitu antara $1-3 \mathrm{~cm}$. Dari belahan akhir tadi kemudian dibuat iratan yang tipis-tipis, setelah dijemur sampai agak kering. Penjemuran ini dimaksudkan untuk memperoleh daya lenting yang kuat, sehingga bambu tidak mudah pecah dan patah. Guna menghindari kemungkinan putusnya iratan, belahlah belahan akhir tadi menjadi dua belahan yang sama tebalnya, tetapi jangan sampai terputus. Kemudian masingmasing belahan ini dibelah lagi menjadi dua, demikian seterusnya.

\section{Penganyaman}


Pendampingan Industri Lokal Anyaman Bambu Untuk Meningkatkan Daya Saing Pasar di Desa Binaan Dusun

Kedampul Kecamatan Tumpang Kabupaten Malang

Proses menganyam ialah metode yang memberi petunjuk agar dapat membuat anyaman dengan semudah-mudahnya dan membawa hasil yang sebaik-baiknya. Motif-motif anyaman yang dipraktikkan meliputi anyaman sasag dan kepang.

\section{Anyaman Sasag}

Prinsip anyaman sasag ialah, mengangkat satu lusi dan menumpangkan satu pakan. Masukkan sehelai pakan, setelah lusi diangkat satu persatu, tahan bagian ujung itu dengan balok agar tidak tercerai berai. Demikian seterusnya dan jangan lupa merapatkannya. Setelah jumlah lungsi dan pakan yang dianyam sama banyaknya maka terbentuklah selembar anyaman, lembaran anyaman ini disebut ilab, yang berdasarkan anyaman sasag.

\section{Anyaman Kepang}

Cara penganyaman pada anyaman kepang, prinsipnya sama dengan anyaman sasag. Hanya pada anyaman kepang jumlah lungsi yang diangkat sebanyak dua helai, baru disisipkan satu pakan. Motif ini terdiri dari beberapa jenis yaitu; 1) anyaman tegak yang dilakukan dengan cara penganyaman pada anyaman kepang, prinsipnya sama dengan anyaman sasag. Hanya pada anyaman kepang jumlah lusi yang diangkat sebanyak dua helai, baru disisipkan satu pakan. 2) anyaman serong yaitu

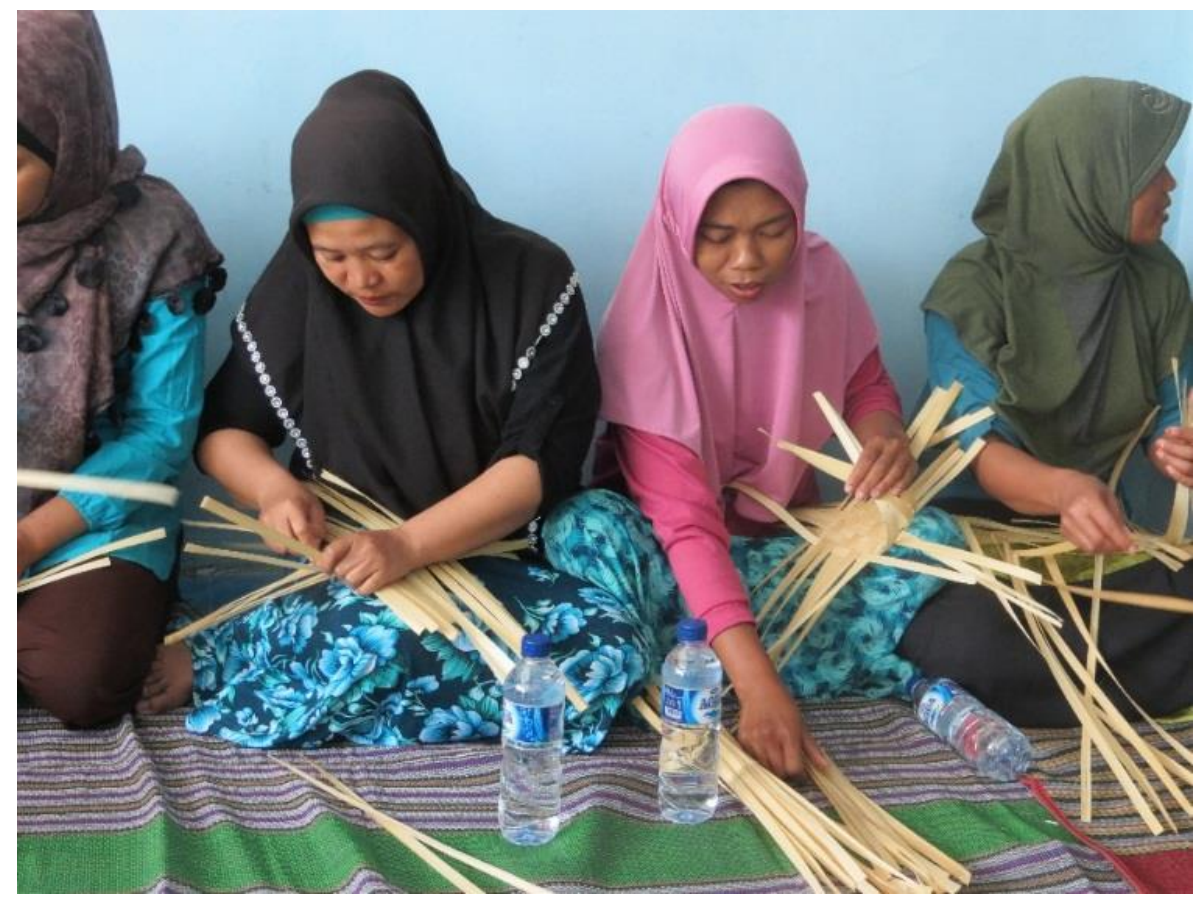

Gambar 2. Proses Penganyaman Bambu oleh Kelompok Pengarajin Bambu

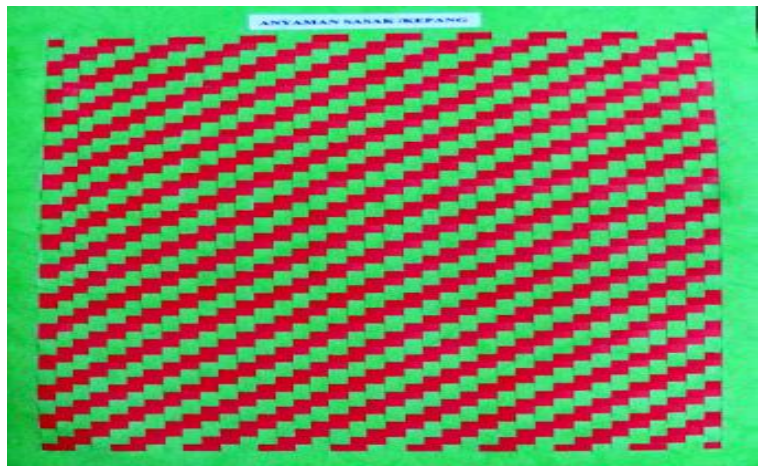

Gambar 3. Motif Anyaman Sasag

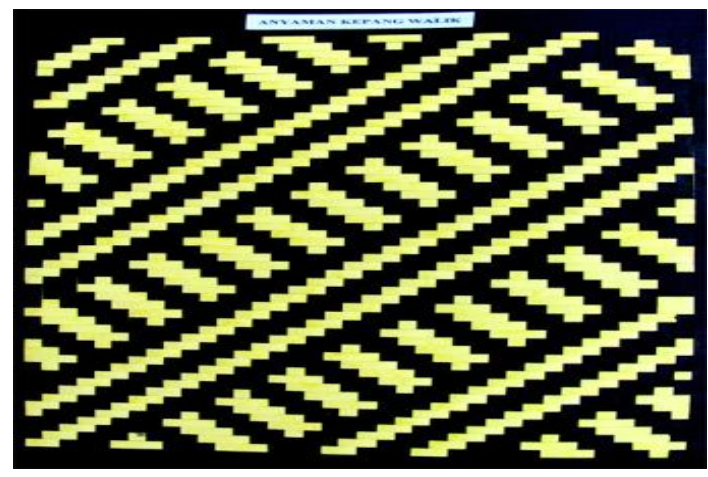

Gambar 4. Motif Anyaman Kepang 
lungsi dan pakannya membentuk sudut sesamanya dan keduanya terletak menyimpang ke kiri dan ke kanan terhadap si penganyam. 3) anyaman kombinasi ialah anyaman perpaduan antara anyaman tegak dan anyaman serong. 4) anyaman pinggir yang berfungsi sebagai penguat atau penahan lembaran anyaman agar tidak mudah rusak atau lolos sekaligus untuk menambah dan meningkatkan daya tarik serta keindahan. Anyaman pinggir dapat dibuat menurut corak (motif) dan variasi sesuai dengan yang dikehendaki. Macam corak dan variasi anyaman pinggir yang mudah dikembangkan dan dimodifikasi menjadi anyaman pinggir yang kuat, indah, dan eksklusif adalah anyaman pinggir bentuk pita, misalnya corak pita tiga, pita empat, pita pucuk, dan sebagainya.

\section{Finishing Produk}

Proses finishing merupakan proses terakhir dari tahap-tahap sebelumnya selesai dikerjakan. Barang-barang yang telah jadi di samping dilihat dari segi, kualitas pengerjaan juga penampilan fisiknya atau finishingnya. Finishing memegang peranan penting dalam menghadirkan produk dari bambu, bahkan pengerjaan yang kurang baik dapat menggagalkan produk yang dibuat. Finishing harus dilakukan dengan teliti dan hati-hati agar tidak kehilangan nilai dari karya tersebut. Adapun tujuan dari finishing adalah sebagai berikut: (1) menghadirkan produk kerajinan bambu dengan berbagai penampilan. b) Agar barang menjadi produk yang indah, menarik mengagumkan dan bernilai tinggi; (2) menutup pori-pori permukaan, menjadikan barang kuat dan tahan lama dari gangguan luar seperti udara, cuaca, hama sehingga barang menjadi awet.

\section{Pemberian Materi: Manajemen Usaha Pemasaran Produk}

Pelatihan manajemen usaha direncanakan dilakasanakan selama 3 kali pertemuan dimana setiap pertemuan dilaksanakan selama 5 jam, namun apabila masih diperlukan maka akan dilakukan penambahan waktu. Pelatihan ini bertujuan untuk: (1) meningkatkan pengetahuan dan jiwa wirausaha para pengrajin; (2) meningkatkan kemampuan pembukuan usaha; (3) meningkatkan pengetahuan dan kemampuan manajemen usaha terutama manajemen pemasaran dalam rangka meningkatkan pendapatan usaha.

Pelatihan manajemen usaha yang akan dilaksanakan berisi antara lain: pelatihan kewirausahaan, pelatihan pembukuan usaha kecil/menengah, dan pelatihan manajemen pemasaran. Secara rinci tahap-tahap pelatihan tersebut adalah: (1) Pelatihan kewirausahaan dengan materi: a) pengenalan ciri-ciri dan watak wirausaha, b) strategi menangkap peluang besar, c) penyusunan rencana bisnis; (2) Pelatihan pembukuan usaha kecil/menengah; (3) Pelatihan manajemen pemasaran meliputi: a) strategi penentuan harga, b) promosi penjualan, c) strategi menghadapi persaingan, dan d) packing dan labeling.

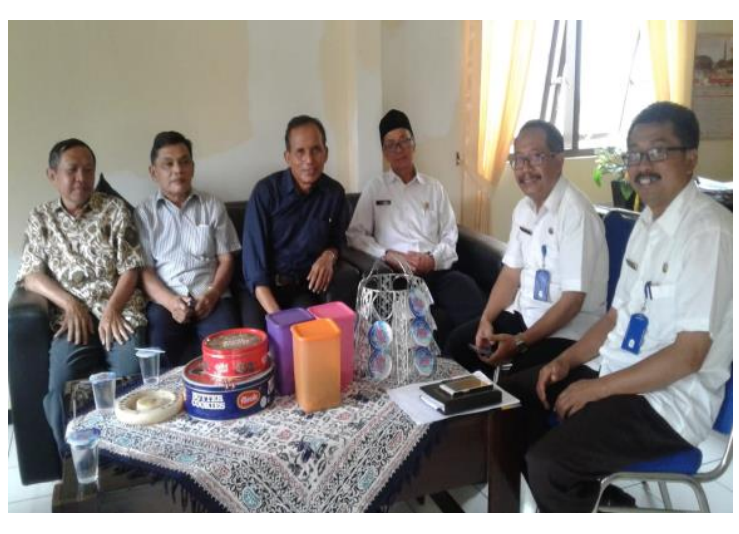

Gambar 5. Tim Pengusul PKM bersama Pemateri

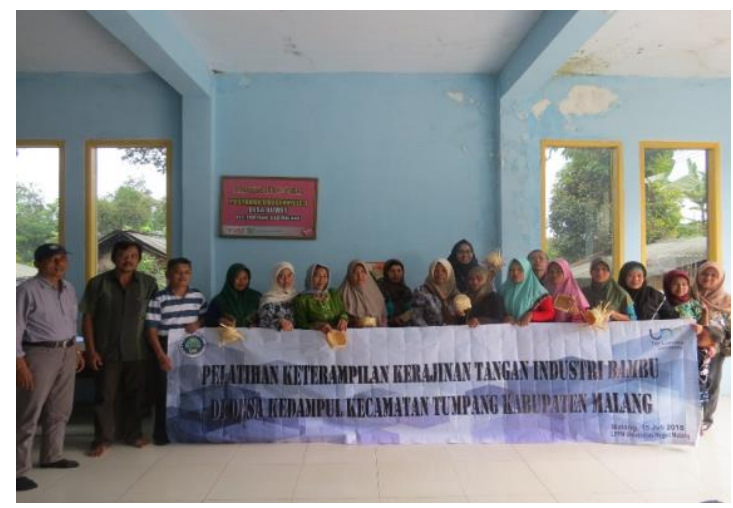

Gambar 6. Tim Pengusul PKM Bersama Kelompok Pengrajin Bambu

Berdasarkan pemaparan hasil pengabdian kepada masyarakat di Dusun Kedampul Desa Duwet Kecamatan Tumpang, Malang menghasilkan: (1) Melalui kegiatan ini telah dihasilkan hasil kerajinan anyaman bambu "besek" dengan inovasi pada jenis anyaman dan warna; (2) Kelompok mitra pada 
Pendampingan Industri Lokal Anyaman Bambu Untuk Meningkatkan Daya Saing Pasar di Desa Binaan Dusun

Kedampul Kecamatan Tumpang Kabupaten Malang

kegiatan dapat mengaplikasikan teknik pembuatan kerajinan anyaman bambu "besek" dengan beberapa jenis anyaman dan warna-warna yang menarik. Melalui inovasi produk maka nilai jual produk akan semakin tinggi; (3) Terjadi peningkatan kemampuan mitra dalam memanajemen usaha yang meliputi inovasi produk, pemasaran, dan pembukuan hasil usaha; (4) Kegiatan ini memotivasi seluruh kelompok anggota mitra.

\section{KESIMPULAN}

Adanya kegiatan pengabdian kepada masyarakat PNPB UM Tahun Anggaran 2018 untuk kelompok pengrajin anyaman bambu di Dusun Kedampul, Desa Duwet, Kecamatan Tumpang, Kabupaten Malang ini, permasalahan yang dihadapi mitra dapat segera teratasi dalam rangka meningkatkan pengetahuan dan pendapatan mitra. Hasil yang didapatkan dari pengabdian kepada masyarakat ini cukup baik, yakni: (1) Kerajinan anyaman bambu "besek" dengan inovasi pada jenis anyaman dan warna; (2) Peningkatan kemampuan dalam menjalankan usaha mitra melalui pendampingan yang diadakan; dan (3) Peningkatan kemampuan dan pendapatan mitra dengan adanya inovasi produk dan manajemen usaha kerajinan anyaman bambu.

\section{SARAN}

Peningkatan transfer teknologi kepada masyarakat kelompok-kelompok usaha mikro hendaknya kegiatan-kegiatan seperti program pengabdian masyarakat perlu digalakkan sehingga kemampuan masyarakat semakin meningkat yang sekaligus meningkatkan kesejahteraan kelompok-kelompok masyarakat usaha mikro.

\section{DAFTAR PUSTAKA}

BPS. 1983 Perkiraan Angka Kelahiran Dan Kematian. Hasil Sensus 1971 dan 1980. Jakarta, 1983.

BPS. 2015. Sensus Penduduk Indonesia Tahun 2010. Jakarta :BPS

Basundara, Brian. 2017. "Penerapan Material Kayu Laminasi Pada Konstruksi Pusat Kerajinan Rakyat di Kota Batu." (Online)

(arsitektur.studentjournal.ub.ac.id/index.php/jma/article/download/98/95)

Dekranas. 2011. Permata Tersembunyi Kalimantan Timur, Seni Kriya Kutai Barat, Malinau, Nunukan. Jakarta: Dewan Kerajinan Nasional.

Farrelly, David. 1996. The Book of Bamboo. London: Thames \& Hudson

Irhas, Edi. 2010. Kerajinan Tangan Dari Bambu.Jakarta: PT Multazam Mulia

Kualisi Kependudukan Jatim, 2014, Data dan Fakta Penduduk Jawa Timur. Surabaya: BKKBN Jatim

McClure, F.A. 1972. Bamboo as a building material. Washington: Departement of Housing and Urban Development.

Mutmainah, Siti. 2014. Karya Kerajinan Anyam dalam Upacara Tradisional di Indonesia. Jurnal Se Kualisi Kependudukan Jatim, 2014, Data dan Fakta Penduduk Jawa Timur. Surabaya: BKKBN Jatim Kualisi Kependudukan Jatim, 2014, Data dan Fakta Penduduk Jawa Timur. Surabaya: BKKBN Jatim ni dan Budaya Padma Vol 9. No 2. September 2014, hal 29-38

Nadeak, Mery Natalia. "Deskripsi Budidaya Dan Pemanfaatan Bambu Di Kelurahan Balumbang Jaya." Skripsi Sarjana, Institut Pertanian Bogor Fakultas Kehutanan Departemen Silvikultur, 2009.

Peraturan Menteri Pekerjaan Umum No.41/PRT/M/2007.

Prabawati, M. N.2016. Etnomatematika Masyarakat Pengrajin Anyaman Rajapolah Kabupaten Tasikmalaya. Infinity Journal, 5(1), 25-31.

Retnowati, 2016. "Pemasaran Kerajinan Besek di Kabupaten Purworejo". Skripsi sarjana agribisnis Fakultas Pertanian Universitas Muhammadiah Purworejo

Suyono, Haryono. 1996 Warta Demografi Edisi Khusus 1997. LD (FEUI)

Swasta, B. 1985. Saluran Pemasaran. BPFE-UGM. Liberty, Yogyakarta.

Swasta dan Irawan, 2001. Manajemen Pemasaran Modern. Liberty. Yogyakarta. 